\title{
Electromagnetic Radiation, a Living Cell and the Soul: A Collated Hypothesis
}

\section{Contzen Pereira}

\begin{abstract}
The soul is believed to be an immortal essence of living things in scores of philosophical and religious traditions but sparsely understood by science. The word 'soul' does not have a scientific definition but through this paper is hypothesized to be an indefinite, non-structured, massless energy made up of electromagnetic radiations that is confined in the cytoskeletal network of the biological cell. Electromagnetic radiations continually interact with the biological cell and propagate within the cell; by a pathway known as 'Cell-Soul Pathway'. This pathway is a coherent, imperceptible, uncontainable and recyclable support pathway, which uses this energy to promulgate consciousness in a biological cell. The cell-soul pathway augments with stress and ceases with death and results in, liberation of the energy as ultra-weak electromagnetic radiations that coalesce with the universe. The cell-soul pathway creates a strong correlation between science and consciousness, and with religion and spirituality.
\end{abstract}

Key Words: soul, electromagnetic radiation, cell-soul pathway, consciousness DOI Number: 10.14704/nq.2015.13.4.862

NeuroQuantology 2015; 4: 426-438

\section{Introduction}

The origination of the soul in science is unsolved, but is more meticulously understood in spirituality and religion as 'entelechy' something complex that emerges when a large number of simple objects are put together. The concept of a soul existed in various pagan religions well before they existed in the monotheistic, traditional world religions. In order to define the soul in science, a logical understanding beyond the scope of religion needs to be provide, whose ultimate goal would be to

\footnotetext{
Corresponding author: Contzen Pereira

Address: Nandadeep, 302, Tarun Bharat Soc, Chakala, Andheri (East), Mumbai 400 099, India.

Phone: + +919819642456, +912266750530

e-mail $\bowtie$ contzen@rediffmail.com, contzen@gmail.com

Relevant conflicts of interest/financial disclosures: The authors declare that the research was conducted in the absence of any commercial or financial relationships that could be construed as a potential conflict of interest.

Received: June 30, 2015; Accepted: October 13, 2015 eISSN 1303-5150
}

amalgamate science and spirituality. The cell-soul pathway is a hypothesis, which will validate this correlation and is wholly an elucidation of my theistic belief. The term 'soul' in this paper represents a scientific entity and should not be linked to the term 'spirit'. Spirit is an individual entity that is represented as an eternal and incorruptible form, a piece of work beyond the scope of science but associated to God, hence is beyond the scope of this paper.

The two oldest forces of energy that exist in nature are electromagnetic force and gravitational force and for an object to be considered as part of the Universe, it must interrelate by means of these forces. Energy is the cause of the universe, which formed from nothingness and thus is the principle of action expressed through change managed by entropy. At the level of a biological cell, entropy reduction arises from internal self-organization, information storage and transfer, and the only www.neuroquantology.com 
way to support the laws of thermodynamics is by balancing these free energy changes with metabolic energy expenditures (Paul et al., 2013) which might be true for all matter. The universe seems, in some sense, to be a living, evolving, adapting universe that utilizes information to organize itself and to create ever-increasing levels of complexity (Mitchell and Staretz, 2011). All material particles are made up of asymmetric form of light which gives moulded matter e.g. a biological cell, the capability to interact and capture this energy, e.g. photosynthesis. The biological cell is an organization of elementary particles, which requires a symmetric energy state, for it to come into existence. The soul on the other hand, is a form of electromagnetic radiation and due to the conserved nature of the universe; a confederation of these two forms creates the magic of life.

Information for the formation and progression of the universe is stored in atoms as charge and spin, with the electron providing low energy to support life and the nuclear constituents such as protons and neutrons providing high energy for the stars (Teilhard de Chardin, 1959). Photons are stable, massless quantum objects that exhibit properties of both wave and particles with observable facts, such as diffraction and interference, on the length scale of its wavelength (Mead, 2000; Okun, 2006). Quantum tunnelling is a concept derived from quantum computing wherein photons travel through specialized cell organelles and elicits signalling by means of movement and interaction of photons within the cell (Hameroff, 1998a; Hameroff, 1998b). The cell-soul pathway supports the concept of quantum tunnelling and therefore helps the circulation of the soul through the cell to root consciousness. When cell death or apoptosis occurs, the cell-soul pathway cease, and the soul is liberated in the form of ultra-weak emissions into the surrounding. This pathway is more rapid than any biochemical or electrochemical process that takes place in the cell and is similar to quantum computing. This pathway and its components can therefore substantiate, that the soul can shape and propagate consciousness in every single biological cell and as these cells grow and reproduce, consciousness also grows. This paper is a compilation of scores of factors, that support the cell-soul pathway and establishes its existence from a scientific stand point, bringing in a correlation between science and religion.

\section{Soul as depicted in Spirituality, Philosophy and Science}

Since the evolution of intelligence, the soul has been widely discussed by many philosophers, theosophists, psychologist and religions. In all the ancient religions, the soul was considered to be a form of reincarnation or transmigration, which has been very well depicted in Hinduism and Buddhism. It was considered to be the source of life that passed on from one body to be reborn in another via the samsaric cycle of life (Brodd, 2003). The samsaric cycles of life was carried out with further incarnations being higher up or lower down in the scale according to a measure of the good and bad actions performed during life, a concept that easily translates into the Christian concept of 'sin'. Plato measured the soul to be the essence of a person which he claimed to be an incorporeal, eternal occupant of the being and upon death exists and is continually reborn to subsequent bodies (Lorenz, 2008; Woods, 1987). Aristotle defined the soul, as a naturally organized body and opposed Plato's idea of the immortality of the soul (Young, 2013; Frede, 1992; Nussbaum, and Rorty, 1992).

Soul as a naturally organized body was elaborated by Ibn Sina and Ibn al-Nafis, who considered the soul to be an outcome of its nature and not a purpose for it to fulfil and so is related to the entire matter, whose character is prepared to receive the soul (Fancy, 2006; Hall, 1979). St. Thomas Aquinas considers the soul to be a working entity, which is not dependent on the body and so could live without a body, making it an indestructible form (Aquinas, 1959; Aquinas, 1984). St. Thomas also points out that one can consistently posit a plurality of souls in a single body only if one conceives of the soul Platonically, which substantiates the existence of several souls in one body (Goyette, 2009). According to Kant, we cannot prove the immateriality of the soul, but can say that all properties and actions of the soul cannot be cognized from materiality (Bishop, 2000). Sigmund Freud a psychologist used a structural model to provide a definite structure to the soul. He divided the soul or psyche into three parts, id, ego and super-ego, which describes the activity and interaction of the body in mental life (Snowden, 2006; Carlson, 2010; Richards, 1977).

According to Christian eschatology, the soul is immortal and is created by God and will be restored through resurrection. At death, the souls 
are judged by God and it is he who decides whether one goes to Heaven or Hell, this wholly depends on the repentance of one's sins (Alcorn, 2004; Wright, 2008). Islam and Judaism follow the same concept but do not consider the act of restoration via resurrection (Thackeray, 1997; Pickthall, 1953). Bahai also considers the soul to be a sign of God, whose evolution always moves away from the material world (Adib, 1966). In Hinduism, Buddhism and Jainism, the soul neither takes birth nor death, but transmigrates from one body to another depending on the deeds performed during its cycle in order to gain knowledge through meditation and realization to return to its state of liberation (Head, 1967; Lopez, 1995). Sikhism considers the soul to be a part of God, because of which the body can sustain life (Singh, 2013). Taoism believes in the body having ten souls and loosing anyone of them could lead to destruction (Kohn, 2000). Chinese believe in the concept of soul dualism, where a person has two or more souls, some souls stay united with the body while the other can leave the body (Hoppal, 1994; Dioszegi, 1962). Based on all the concepts provided by every religion, it seems that God is always in the glare of publicity and holds the key to the privilege of souls, deciding their fate between heaven, hell and the in-between.

Science cannot define the soul but there have been attempts of proving the existence of the soul but the major drawback lies in its definition which ferries between domains of science and religion, making it difficult to determine its stance. The soul and consciousness has always been perpetually linked to the brain and based on such principles, is obligated to reside there, managing the level of consciousness through selfishness. Neuroscientists have been studying the development of mind alongside the development of the brain to understand the phenomena of human thought and behaviour (Snead, 2010; Kandel et al., 2012; Squire et al., 2012) based on which the existence of the soul can be determined. Huter suggested, that life is based on radiation and he established the hypothesis that the physical matter is not merely based on the static i.e. magnetic force in the atomic nucleus, but also as the dynamic energy i.e. electrical power in the electron sheath of the atomic model, but in addition also bears a spiritual energy. He positioned this so-called "sensitive energy" as an elementary force into matter. According to his belief, this energy drives the evolution process leading to increasing consciousness from minerals, plants and animals to human (Niggli, 1998). Quantum physics has the ability to define the soul but gets spellbound within laws that cannot scientifically define its existence under a hot, wet and noisy biological environment.

For all of these theories, philosophies and scientific explanations, there exists a rendering of selfish thought, that the soul can only be related to the body, brain and mind of multicellular beings. Very few religions, philosophies and scientific theories state the existence of the soul as a form of energy in a unicellular form i.e. in a single cell. This paper is a collection of scientific evidences and hypothesis which extrapolates the existence of the soul as an energy that promulgates consciousness in a single biological cell.

\section{Electromagnetic force and the biological cell}

Electromagnetic spectrum is made up of radiation and is differentiated based on three physical properties; frequency, wavelength and photon energy. Based on wavelength, electromagnetic radiation is classified into radio waves, microwaves, tetra hertz radiation, infrared radiations, visible light, ultraviolet light, $\mathrm{X}$-rays and gamma rays. When electromagnetic radiation interacts with single atoms and molecules, the interactive behaviour observed would depend on the amount of energy present per photons, as this energy would describe the effect on the atoms and molecules. Electromagnetic radiation behaves as a wave and a particle and this property is known as waveparticle duality or photoelectric effect (Mehta, 2011; Elert, 1998).

The phototrophic way of life in living systems, is trapping of electromagnetic radiation energy, its conversion into chemical energy and its use for cellular maintenance and growth (Overmann and Garcia-Pichel, 2006). The effect of electromagnetic radiations on biological systems depends on radiation strength and its frequency; these properties play an important role in energy transfer. Higher frequency radiations such as $\mathrm{X}$ rays and gamma rays can cause irreversible molecular damage and are harmful to biological systems. On the other hand, near infrared and visible light support the 
biological cell and participate in various cellular functions, the best example would be photosynthesis, where photomolecules are excited via the process of non-photochemical quenching and bring about Adenosine Triphosphate (ATP) production within the cell.

Maximum perpetration and absorption of light takes place in the zone of near infrared light $(650-1350 \mathrm{~nm})$. Water absorbs electromagnetic radiation in the range of $250-1000 \mathrm{~nm}$, and since it forms the major constituent of the biological cell, it supports scattering of light that plays an important role in photon penetration. Photon penetration was demonstrated by Popo and Klimek as photon sucking, which involves active absorption and re-absorption of emitted radiation that supports biological regulation within the cells and tissue (Popp and Klimek, 2007). Vogel et al demonstrated this phenomenon in bacteria, where some bacterial species suck up radiations from their nutrition medium (Vogel and Submuth, 1998). In the cell cytoplasm, it has been predicted that, the low damping effect of micro volumes of water within the cell, play a major role in maintaining stability and bring about signal amplification by means of water-molecule oscillators functioning as synchronized oscillations or regenerative amplifications (Preparata, 1995; Del Giudice et al., 2002; Zhadin and Giuliani, 2006; Sinitsyn et al., 2000).

Most living systems function under the conditions of constant sunlight or by natural electromagnetic forces which exists over a wide spectral range. Electromagnetic force generation is given by Maxwell's equations, wherein a static electric field is generated by a static charged particle and both an electric and magnetic field is generated, if a charged particle moves at a constant velocity. Upon acceleration the charged particle oscillates, resulting in the electric and magnetic fields to oscillate and this creates an interconnection between oscillating magnetic and electric fields. The radiated electromagnetic field is called an electromagnetic wave or radiation that carries energy and if the energy is high and approaches the optical part of the electromagnetic spectrum, the waves generated start behaving as particles while interacting with matter (Cook et al., 1985; Glauber, 1992). Max Planck, postulated a theory, now known as the Planck postulate, which describes how all matter absorbs and re-emits photons i.e. quanta of energy, from and into the quantum foam of the eISSN 1303-5150 zero-point field (ZPF) that pervades all matter and even the vacuum of space (Haisch et al., 1997). Normally these emissions are random exchanges of energy between particles and the ZPF but in living tissue have been shown to exhibit quantum coherence and also carry information non-locally i.e. instantaneous transmission of information across space and time (Darling, 2005).

Photons that are delivered into the cell can be absorbed, scattered or reflected. The scattering behaviour of the cell is an important feature, because it determines the volume distribution of light intensity in the cell (Chung et al., 2012; Tuchin, 1997). Scattered photons are eventually absorbed or will escape in the form of diffused reflection but absorbed photons interact with organic molecules or photo molecules. Absorption of photons occurs, when a charged particle moves from a higher energy excited state to lower energy ground state i.e. hf = E2-E1, where $\mathrm{h}$ is the Plank's constant, $\mathrm{f}$ is the frequency of the photon, E2 is the energy of the excited state and E1 is the energy of the ground state and brings about a release of a photon (Marston, 1999) leading to an optical window effect in the cell. Scattering and internal conversion of light has also been observed in non-invasive medical techniques such as photobiomodulation and low level light therapy, wherein light is used in various therapeutic techniques. In these practices, red and near infrared light is known to produce a significant shift in the overall cell redox potential of the cells, which leads to greater oxidation and increased proton pumping in the mitochondria for more production of ATP (Hashmi et al., 2010; Chung et al., 2012).

The environment and the cellular components play an important role in sieving of electromagnetic radiation. According to Letokhov theory, the wide spectrum of UV light (230-280 $\mathrm{nm}$ ) is completely absorbed by the ozone layer, where the level of the photons drops to 1013 to ca. 10-27 photon $/ \mathrm{cm}^{2}$ s while passing through the atmosphere (Musumeci et al., 1999) while Larger proposed a model, wherein electromagnetic forces can be altered by the light-absorbing cell components which acts like a spectrum filter (Laager, 2008). From a biophysical stand point of a cell, static and low frequency electric fields get eliminated due to the presence of ions in the cell cytoplasm and this allows only minimal electric field penetration into the cell (Marino and Becker, 1977; Robinson, 1985; Portier and Wolfe, 
1998). Balzano has shown that a non-linear interaction could be due to scattering of electromagnetic forces from molecule oscillators located in the strong electric field gradients such as the membrane surfaces which could modulate frequencies of different electromagnetic forces that could induce bio effects to the cell (Balzano and Sheppard, 2003; Balzano and Sheppard, 2007).

Schrödinger proposed that in living cells the high level of organization can only be maintained because the cellular system perpetually obtains order from the environment. According to Schrödinger sunlight provides this miraculous order (Chang et al., 1998; Popp and Beloussov, 2003). Herbert Fröhlich supported this idea by introducing the concept of coherence in a living system, where he associated absorbed light to a laser light, an ultra-weak radiation that is calm with stable intensity and can superpose (Hyland, 2000). He also postulated that biological systems exhibit coherent longitudinal vibrations of electrically polar structures (Fröhlich, 1968; 1969). The Fröhlich model states that, when the energy supply goes above a certain level, the polar structure enters into a state of non-linear vibration and stores energy in an orderly fashion that is expressed in a long range phase correlation of super fluidity and super conductivity (Fröhlich, 1970; 1972; 1975). These ideas proved that, coherent behaviour of biophotons observed in living systems are similar to the coherent behaviour found in superconductors. The only difference is that in superconductors, this behaviour is observed with the help of Bose-Einstein condensation at temperatures near the absolute zero point (Niggli, 2014) while coherence in biological systems occurs at room temperature.

Most communications within or between cells occurs via chemical or electrical signalling. The first known cellular communication was demonstrated by Alexander Gurwitsch where he showed an increase in mitosis, in a set of chemically isolated onion root cells present in a zone of actively dividing cells and called it "mitogenetic radiation" which was electromagnetic in nature (Gurwitsch, 1923; 1924; Gurwitsch and Gurwitsch, 1924). Maxwell's theory of electromagnetism considers slow varying electric fields as "static" or quasi-static" which may be involved in significant cellular properties such as distribution of ions (McCaig et al., 2005; Levin, 2003) but cannot be considered eISSN 1303-5150 as a mechanism for long-distance communication. In cells, electromagnetic radiations were first described in the visible spectrum, where "emanations" of light from biochemical processes of yeast cells were detected using photographic plates (Scheminzky, 1916). Low frequency electromagnetic force is known to affect various cell functions, including cell proliferation and differentiation, apoptosis, DNA synthesis, RNA transcription, protein expression, ATP synthesis and metabolic activity (Foletti et al., 2009; Lisi et al., 2006; 2008a; 2008b; Ventura et al., 2005; Santini et al., 2005; Litovitz et al., 1994; Goodman and Blank, 2002; Goodman and Henderson, 1988; Sun et al., 2001; Zrimec et al., 2002; Milani et al., 2001).

Biophotons or ultra-weak photon emission is a very well researched concept under the studies conducted by Popp and his group, where cells usually emit one to thousands of photons/s $\mathrm{cm} 2$. Biological cells are known to show increased intensity of these emissions, when they undergo physiological changes under chemical or physical stress (Slawinski, 1990; Slawinski, 2003) or a "flash of death" when the cells get damaged beyond repair. The cytoskeleton is expected to be a source of vibrations that generate cellular electromagnetic forces at $\mathrm{kHz}-\mathrm{GHz}$ range which is also connected to the metastatic growth of this network (Pokorny, 2005; Pokorny, 2006; Pokorny,2009). Budagovsky et al and Borodin et al. have used the degree of spatial coherence and showed that, the order in biological cells influences the coherence properties of ultra-weak emissions (Budagovskii et al., 2001; Borodin et al., 2008). Dying cells lose the ability of light memorization and therefore before death a significant increase of ultra-weak photon emission is observed. In short, their capacity to store energy of light is lost. A similar event although much slower is happening in the cells during the processes of aging. In case of cancer cells, the cellular toxins accumulated during the years leads to deposits of cellular debris in the tissues (e.g. arteriosclerosis in blood vessels), this is known to induce increased emission of biophotons (van Wijk et al., 2013; Niggli et al., 2005).

Living cells perform copious, complicated, synchronized tasks in order to maintain their customary involuntary biological functions. These responsibilities require information input as a chemical gradient, information processing in the form of signals and instructions to reorganize www.neuroquantology.com 
e.g. the cytoskeleton for motility (Rosen, 1991). These tasks are performed by smaller machine like entities called organelles that function by means of energy input and output mechanisms, using the important macromolecule ATP for energy (Maturana and Varela, 1980; Alberts, 1994). Cells obey the laws of physics, such as the first law of thermodynamics and hence can be viewed as a thermodynamic machine but simultaneously it locally acts against the second law of thermodynamics by creating structural and functional order i.e. it creates and maintains information by expending energy produced from nutrient in the form of ATP and Guanosine Triphosphate (GTP) molecules. Therefore, it's safe to say that living cells can be viewed as both micro-factories with nano-machines performing individual tasks and biological computers whose nano-chips are the various proteins and peptides in addition to DNA and RNA (Davies et al., 2013). All of these scientific findings support the existence of the supplementary pathway called as the cell-soul pathway, which is one of the many work functions and pathways that exist within the grand domain of a biological cell.

\section{Cell-Soul Pathway}

The cell-soul pathway is a hypothetical scientific pathway that helps in propagation of the soul and provides support to a biological cell and its functions. The pathway propagates the soul in the form of immeasurable assortment of photons of different frequencies and wavelengths within the cytoskeletal network of the cell (Figure 1). The source of these photons is trapped electromagnetic radiation that prevails in the universe and the formation of the soul wholly depends on the organization of matter which makes up the cell, its components and biochemical systems. On disentanglement or release, the soul loses its identity and merges with the electromagnetic radiation in the cosmos, an involuntary cycle that cannot be changed or altered. The cell-soul pathway is a present ultrafast process, that runs concurrently with all other biochemical processes in a cell and is persistently interacting and supporting these processes to provide life; differentiating non-living from the living.

Cells have cellular components which perform specific functions that are encoded as genes in the DNA and RNA. Cellular components, though common in all cells, differ between cells eISSN 1303-5150 (e.g. unicellular or multicellular organisms or based on evolutionary classes - archae, prokaryotes or eukaryotes) based on their type and function. The soul interacts with the cell, only if the structure and cellular processes of a cell are primed; in the absence of these structures, the soul propagation gets altered. The cell-soul pathway is a unique and untouched pathway that has been prevailing since life came into existence and maintains obedience in its interaction with various cellular functions. The propagation of the cell-soul pathway by electromagnetic radiation can be demonstrated by photobiomodulation or low-power laser therapy techniques, which are used to treat damaged cells under stress, by generating ATP through light. Photobiomodulation is being widely used by physiotherapists to treat a wide variety of acute and chronic musculoskeletal aches and pains, dentists to treat inflamed oral tissues, and to heal diverse ulcerations, dermatologists to treat oedema, indolent ulcers, burns, dermatitis, rheumatologists relief of pain, treatment of chronic inflammations and autoimmune diseases, and by other specialists e.g., for treatment of middle and inner ear diseases, nerve regeneration, some of which are yet to be identified (Karu, 2014; Tuner and Hode, 1999; Baxter, 1994; Simunovic, 2000).

Electromagnetic radiation is made up of a wide spectrum of wavelengths which can be harmful at higher frequencies and energies. The cell membrane and cytoplasm act as the first barrier for penetration of electromagnetic radiation and protects the cell, by mechanisms such as selective absorption, scattering, reflection and re-absorption. This is the first step of soul formation in the cell-soul pathway and helps in trapping of the soul and in its transmission (Figure 1). Micro volumes of water inside the cell also help in maintaining temperature variations that take place in cell cytoplasm due to absorption of electromagnetic radiations. Low damping effect of micro volumes of water inside the cell brings about photon amplification, by means of water-molecule oscillators, which function as synchronized oscillations or regenerative amplifications (Preparata, 1995; Del Giudice et al., 2002; Zhadin and Giuliani, 2006; Sinitsyn et al., 2000) supporting the dissemination of the soul in the cell-soul pathway.

Selective absorption of photons and filtration through the cell membrane leads to www.neuroquantology.com 
differentiation of light particles or photons with reduced frequencies and intensities. The low frequency photons with moderate amounts of energies get absorbed and excite photomolecules present in the cell. The excitation of these molecules by the absorption of photons brings about a change of state i.e. electrons shift from a ground state to an excited state and back, leading to a release of low frequency photons, which activate a cascade of electron excitations and photon releases within the cell.

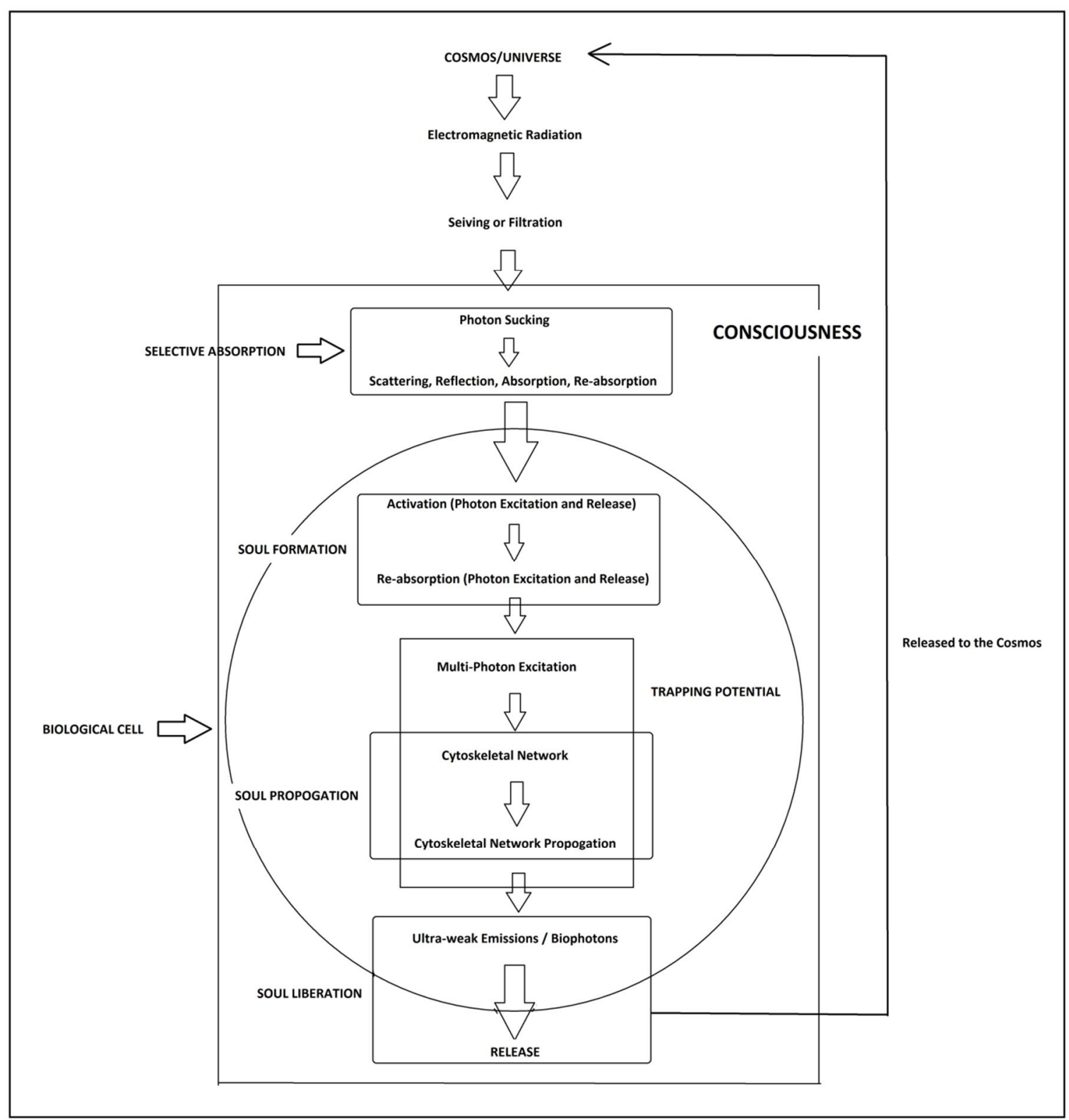

Figure 1. The Schematic Representation of the Cell-Soul Pathway.

This is the second step of the cell-soul pathway, as here is where the soul takes form, with the increase in number of ultra-weak emissions that bring about the transmission of the soul across the cell. The transmission of these photons is ultra-fast in comparison to any of the cellular biochemical processes, where searching, processing and retrieval of stored information from previous experiences are analysed and then used to activate the needed processes in the cell. Such a precise activation and progression of information, clearly demonstrates the capability of the cell-soul pathway to advance consciousness in the cell. Schrödinger and Fröhlich, demonstrated the coherence behaviour of these excitations which were comparable to 
the coherent behaviour found in super conductors for ultra-fast transmission of information (Chang et al., 1998; Popp and Beloussov, 2003; Niggli, 2014).

Popo and Klimek have shown the principle of photon sucking by which radiation becomes partially re-absorbed as soon as it is emitted by the tissue or cell (Popp and Klimek, 2007). As per the laws of physics, a molecule cannot absorb low energy photons to emit high energy photons, but this can be overcome by the cell through the property of multi-photon excitation, which results in emission of a higher energy photon, if two low energy photons are absorbed (Sun et al., 2010). Excitation, release and absorption of photons, is a key process in the cell-soul pathway that can be proved by the existence of biophotons or ultra-weak photon emissions demonstrated by Popp and his group. Biophotons are known to show increased intensity when they undergo physiological changes under chemical or physical stress (Slawinski, 1990; 2003) or a flash of death when the cells get damaged beyond repair (Scheminzky, 1916) indicating increased absorption of electromagnetic radiation leading to amplified cell-soul pathway activity under cellular stress. At a given time within the cell, there is an assortment of photons which are at different frequencies and wavelengths and are not constant. Which wavelength supports which activity in the cell still remains unclear, as the release of ultra-weak emissions occurs in a broad range of $280-800 \mathrm{~nm}$ (Maricella and Pierre, 2006). The soul therefore remains immeasurable and non-quantifiable in the cell-soul pathway but promulgates major energy transformations within the cell.

Coherence and temperature are key factors in conductance of photons in the cell-soul pathway. As per the Fröhlich model, biological systems exhibit coherent longitudinal vibrations of electrically polar structures which results in storage of energy in an orderly fashion and is expressed as super fluidity and super conductance (Fröhlich, 1970; 1972; 1975). Coherence in biological systems is demonstrated by the perfect similarity between the photon count statistics of biophotons and a Poissionian distribution for both stationary and dynamic fields (Popp, 2003). In view of energy conservation, destructive interference occurring outside the cell has to be compensated by constructive interference inside the cell, which was predicted by the Dicke model (Popp et al., eISSN 1303-5150
1994). Once excited, the cells may require up to days until the level of spontaneous optical activity is restored i.e. after the excitation phase is followed by delayed luminescence (Cifra et al., 2011) proving that the soul can support a cell for many days and when photon activity reduces, it is refilled by sucking in electromagnetic radiations from the environment. This re-engages the whole cell-soul cycle and a series of excitations and absorptions begin to propagate the soul. Wijk has explained this activity as energy pumping, which promotes an electron to an excited level and radiation relaxation, which creates a photon and brings about its release (van Wijk, 2001). Cellular activities such as cell damage, cell infiltration, cell growth, cellular respiration, cellular division, etc can result in higher sucking of the electromagnetic radiation and enhanced cell-soul activity to overcome the stress induced to the cell.

The third step of the cell soul pathway is the process of "trapping potential" by the cytoskeletal network of the cell, which promotes movement of the soul within the cell (Figure 1). In the "trapping potential" process, photons are condensed and lose their identity and behave like clones of each other forming the Bose-Einstein Condensate or Fröhlich Condensate (Fröhlich, 1968; Fröhlich, 1969). The condensation of photons formed at room temperatures; activate the cytoskeletal molecular structure and bring about a message transfer. Cytoskeletal structures such as microtubules in the brain cells have demonstrated this message transfer via the Orch OR theory penned by Roger Penrose and Stuart Hameroff (Hameroff and Penrose, 2014). Penrose and Hameroff claim that constant formation and reformation of tubulin states in the cytoskeleton are governed by quantum mechanical effects within each tubulin interior and these effects function as a quantum computer using "quantum bits" that interact non-locally with other tubulins and with quantum holograms. When enough tubulins are entangled long enough to reach a certain threshold, a "conscious event" occurs (Hameroff, 1998a; 1998b). Jibu and Hameroff conclude from the constant inner diameter of cytoskeletal structure that it is capable of guiding light, free of thermal noise and loss (Jibu et al., 1994).

The dipole characteristics of the cytoskeletal molecules also play an important role in the propagation of the soul by means of the cell-soul pathway. These dipole states www.neuroquantology.com 
mediate computation and entanglement as electric or magnetic, the latter being more prominent as demonstrated by "Bandyopadhyay Coherence" at alternating currents of gigahertz, megahertz and kilohertz frequencies at room temperature (Sahu et al., 2013a; 2013b). The entanglement and interference patterns within the cytoskeletal network have been shown to form holographic images by the presence of a negative refractive index similar to a form of material called metamaterial. Metamaterial is an artificial material engineered to have a negative index which permits the creation of super lenses that can have a spatial resolution below that of the wavelength (Veselago, 1968; Ung, 2009; Veselago et al., 2006). This structural behaviour observed in the cells support the cell-soul pathway broadcast and promotes the storage and retrieval of stored data and memory as holographic qubits. The soul in the cell-soul pathway takes shape in the form of holographic qubits and elevates consciousness in the cell for co-ordination of various cellular activities. All cellular activities are carried out via the cell-soul pathway that proliferates through, constant excitation and absorption of photons within the cell cytoplasm and cytoskeletal network. The fourth step of the cell-soul pathway is destructive interference, where the cell-soul pathway completes its cycle by releasing ultra-weak emissions or biophotons. Destructive interference does not increase linearly but follows the effective amplitude of the interference patterns of the biophoton field. Therefore, the zone of most effective destruction according to energy conservation law is at the same time the zone of highest efficacy in storing light within the organism to establish communication (Popp, 2003).

Death of a cell due to aging or a sudden event, results in ceasing of the rhythmic biochemical cycles that are managed within the cellular processes of the cell. A breach in the cellular process, would lead to a stoppage in the cell-soul pathway which may recover by increased absorption of electromagnetic radiation from the environment. If this exchange or recovery is not swift, it would lead to cell death, which will result in the release of the soul from the cell. This was demonstrated in biological cells which showed a rapid increase in ultra-weak emission, an activity termed as "flash of death" (Slawinski, 2005). The cell soul-pathway is purely a scientific pathway which supports important

eISSN 1303-5150 roles in cell functions, including cell proliferation and differentiation, apoptosis, DNA synthesis, RNA transcription, protein expression, ATP synthesis and metabolic activity. These cellular activities are all managed by cellular consciousness by means of the cell-soul pathway and once the message is recorded, it gets reiterated by means of this involuntary pathway until death of the cell. Ultra-fast networking in gigahertz, megahertz and kilohertz frequencies is required for the propagation of consciousness and can be clearly demonstrated by the cell-soul pathway.

\section{Correlation of the cell-soul pathway, consciousness and religion}

Lynn Margulis, in endosymbiotic theory of organelle evolution, provides a definition of consciousness and intelligence: "Not just animals are conscious but every organized being is conscious. In the simplest sense, consciousness is an awareness (has knowledge) of the outside" (Margulis and Sagan, 1995). A Chilean biologist and philosopher Humberto Maturana wrote that "Living systems are cognitive systems and living as a process is a process of cognition. This statement is valid for all organisms with and without a nervous system" (Maturana, 1970). Consciousness is the ability to be aware of and to be able to perceive the relationship between one's self and one's environment. It is also to be associated with the ability to process, store and act on information gathered from the external environment (Mitchell and Staretz, 2011). The information of consciousness gained by the movement of the soul, resides in patterns of matter and energy, which are build up in the cell based on prior experiences with more interaction and knowledge. The quantum hologram theory by Marcer proposes that, life at the most basic level such as primitive cells exchange information with the environment by utilizing the quantum coherence of non-locality (Hameroff, 1998) which is an attribute demonstrated by the cellsoul pathway (Figure 1).

Perception is the ultimate goal of cellular evolution and consciousness is an outgrowth of abilities and together with transmission of the cell-soul pathway helps the cell evolve to higher levels. Consciousness is known to increase with increased mentality and complexity of evolution (Mitchell and Staretz, 2011). A biological cell demonstrates consciousness built by the 
quantum principles of entanglement, coherence and non-locality as explained by the cell-soul pathway. The cell-soul pathway can hence be considered as the basis of consciousness in a cell and is openly exhibited by conscious processes such as quorum sensing in bacterial cells. Quorum sensing in bacteria is a conscious decision taken by the bacteria to coordinate certain behaviours such as bio-film formation, virulence and antibiotic resistance which depends on the local density of the bacterial population (Miller and Bassler, 2001).

Many theories suggest that consciousness can be viewed from the standpoint of evolutionary biology as an adaptation in the sense of a trait that increases fitness (Nichols and Grantham, 2000). Peter Carruthers states that consciousness allows living organisms to make distinctions between appearance and reality (Baars, 1993). Based on this theory and its correlation to the cell-soul pathway, we can confirm that consciousness propagated by the soul enables the cell to understand and judge perceptions giving the cell a prospect to behave as per will. The relationship between the universe and subjective consciousness can be explained by cosmic-symmetry breaking and it's only through the consensual regularities of subjective consciousness that a cell comes to know the real world (King, 2011) The cell-soul pathway helps in cosmic symmetry breaking

\author{
through biogenesis and evolutionary \\ diversification because of which a cell can evolve \\ and diversify with the help of its soul cultivated \\ consciousness.
}

Science cannot explain consciousness from a materialistic world view and neither can religion explain evolutionary principles in nature without adapting the scientific world view. In other words, science without religion is lame and religion without science is blind. Science, religion, subjective and objective experiences are all products of consciousness but science and religion were both created by consciousness as part of evolution yet neither science nor religion knows what consciousness is.

\section{Conclusion}

This paper validates the reason for the existence of the soul as a form of energy in the cell-soul pathway, which brings in a formidable relationship between science and consciousness, facilitated by religion and spirituality. Spirituality can be accomplished when consciousness derived from the cell-soul pathway is healthy, open, alert and expansive, but is mystified when consciousness is cramped, constricted, chaotic and detached. The soul is a conduct for consciousness which has always existed in all living cells; the magical blocks that make life. 
References

Adib T. The Revelation of Bahá'u'lláh, Volume 1. Oxford, UK. 1976.

Alberts B, Bray D, Lewis J, Raff M, Roberts K, Watson JD. Molecular Biology of the Cell. Garland Publishing; New York, 1994.

Alcorn RA. Heaven (Sandy, OR: Eternal Perspective Ministries). Alcorn devotes an. Appendix to the topic, Christoplatonism's False Assumptions, 2004; 475-482.

Aquinas T. "Super Boetium De Trinitate" (in Latin), 1959.

Aquinas, T. Questions on the Soul, q. 9, trans. James H. Robb (Milwaukee: Marquette University Press) 1984.

Baars B. A Cognitive Theory of Consciousness. Cambridge University Press. 1993.

Balzano Q and Sheppard A. RF nonlinear interactions in living cells-I: nonequilibrium thermodynamic theory. Bioelectromagnetics 2003; 24 (7): 473-482.

Balzano $Q$ and Sheppard A. Erratum $R F$ nonlinear interactions in living cells-i: nonequilibrium thermodynamic theory. Bioelectromagnetics 2007; 28 (1): 47.

Baxter GD. Therapeutic Lasers. Theory and Practice. 1994 Churchill Livingstone, London.

Bishop P. Synchronicity and Intellectual Intuition in Kant, Swedenborg, and Jung. USA: The Edwin Mellen Press. 2000; pp.262-267.

Borodin I, Budagovskii A, Budagovskaya 0, Budagovskii I and Sudnik Y. Using the effect of photo induced variability of optical properties of chlorophyll-containing tissues for diagnosing the functional state of plants. Russian Agricultural Sciences 2008; 34 (5): 357-359.

Brodd J. World Religions. Winona, MN: Saint Mary's Press, 2003.

Budagovskii A, Turovtseva N and Budagovskii I. Coherent electromagnetic fields and remote cell interaction. Biofizika 2001; 46 (5): 894-900

Carlson NR. Psychology the science of behaviour: The psychodynamic approach. USA: Pearson Canada. 2010; p. 453.

Chang JJ, Fisch J and Popp FA. Biophotons, 1998. Kluwer Academic Publishers, Boston.

Chung H, Dai T, Sharma SK, Huang Y, Carroll J and Hamblin MR. The Nuts and Bolts of Low-level Laser (Light) Therapy. Ann Biomed Eng 2012; 40(2): 516-533. doi:10.1007/s10439-011-0454-7.

Cifra M, Fields JZ, Farhadi A. Electromagnetic cellular interactions, Prog Biophys Mol Biol 2011; 105: 223-246.

Cook RJ, Shankland DG and Wells AL. Quantum theory of particle motion in a rapidly oscillating field. Phys. Rev. A 1985; 31: 564

Darling D. Teleportation - The Impossible Leap, John Wiley \& Sons. Hoboken, NJ, 2005.

Davies PCW, Rieper E, and Tuszynski JA. Self-organization and entropy reduction in a living cell. Biosystems, 2013; 111(1): 1-10.

Del Giudice E, Fleischmann M, Preparata G and Talpo G. On the "unreasonable" effects of elf magnetic fields upon a system of ions. Bioelectromagnetics 2002; 23: 522-530.

Diószegi V. Samanizmus. Élet és Tudomány Kiskönyvtár. Budapest: Gondolat 1962.

Elert G "The Electromagnetic Spectrum, The Physics Hypertextbook". Hypertextbook.com. 1998. Retrieved 2015-03-01.

Fancy NAG. Pulmonary Transit and Bodily Resurrection: The Interaction of Medicine, Philosophy and Religion in the Works of Ibn al-Nafīs (d. 1288)", 2006; p. 209-210, Electronic Theses and Dissertations, University of Notre eISSN 1303-5150
Dame.

Foletti A, Lisi A, Ledda M, de Carlo F and Grimaldi S. Cellular ELF signals as a possible tool in informative medicine. Electromag Biol Med 2009; 28 (1), 71-79.

Frede M. "On Aristotle's Conception of the Soul", in Nussbaum \& Rorty, 1992; 93-107.

Fröhlich H. Bose condensation of strongly excited longitudinal electric modes. Phys Lett A 1968; 26: 402403.

Fröhlich H. Quantum mechanical concepts in biology. In: Marois, M. (Ed.), Proceedings of First International Conference on Theoretical Physics and Biology, 1967; pp. 13-22

Fröhlich H. Long range coherence and the action of enzymes. Nature 1970; 228: 1093.

Fröhlich H. Selective long range dispersion forces between large systems. Phys Lett A 1972; 39 (2): 153-154.

Fröhlich H. The extraordinary dielectric properties of biological materials and the action of enzymes. Proc Natl Acad Sci USA 1975; 72 (11): 4211-4215. URL. http://www.pnas.org/content/72/11/4211.abstract.

Glauber RJ. Quantum Theory of Particle Trapping by Oscillating Fields. Quant Measure in Optics NATO ASI Series 1992; 282: 3-14.

Goodman R and Henderson A. Exposure of salivary gland cells to low-frequency electromagnetic fields alters polypeptide synthesis. Proc Natl Acad Sci USA 1988; 85 (11): 3928

Goodman $\mathrm{R}$ and Blank $\mathrm{M}$. Insights into electromagnetic interaction mechanisms. J Cell Physiol 2002; 192 (1): 1622.

Goyette J. St. Thomas on the Unity of Substantial Form. Nova et Vetera, English Edition, 2009; 7 (4): 781-90.

Gurwitsch A. Die Natur des spezifischen Erregers der Zellteilung. Archiv für Entwicklungsmechanik der Organismen 1923; 100 (1-2): 11-40.

Gurwitsch A. Physikalisches über mitogenetische Strahlen. Archiv für Entwicklungsmechanik der Organismen 1924; 103 (3-4): 490-498.

Gurwitsch A and Gurwitsch N. Fortgesetzte Untersuchungen über mitogenetische Strahlung und Induktion. Archiv für Entwicklungsmechanik der Organismen 1924; 103 (1-2): 68-79.

Haisch B, Reuda A and Putoff H. Physics of the Zero Point Field: Implications for Inertia, Gravity andMass, Spec Sci Technol, 1997; 20: 99-114.

Hall E. A Decisive Example of the Influence of Psychological Doctrines in Islamic Science and Culture," J History Arabic Sci 1979; 3: 46-8.

Hameroff S. Quantum computation in brain microtubules? The Penrose-Hameroff Orch OR model of consciousness. Phil Trans R Soc Lond A 1998a: 356: 1869-1896.

Hameroff S and Penrose R. Consciousness in the universe. A review of the 'Orch OR' theory. Phys Life Rev 2014; 11: 39-78.

Hashmi JT, Huang Y, Sharma SK, Kurup DB, De Taboada L, Carroll JD and Hamblin MR. Effect of Pulsing in LowLevel Light Therapy. Lasers Surg Med. 2010; 42(6): 450466. doi:10.1002/lsm.20950.

Head J Reincarnation in World Thought; A W Holzer, Born Again, 1967.

Hoppál M. Sámánok. Lelkek és jelképek. Budapest: Helikon Kiadó. Title mans: "Shamans / Souls and symbols". 1994.

Hyland GJ. Physics and biology of mobile telephony. Lancet 2000; 356: 1833- 1836.

Jibu M, Hagan S, Hameroff SR, Pribram KH and Yasue K. Quantum optical coherence in cytoskeletal microtubules: www.neuroquantology.com 
implications for brain function. Biosystems 1994: 32(3): 195-209.

Kandel ER, Schwartz JH, Jessell TM, Siegelbaum SA, Hudspeth AJ. Principles of Neural Science. Fifth Edition, 2012. .

Karu TI and Molecular Mechanisms of Photobiomodulation (Low-Power Laser Therapy). Selected Topics in Quantum Electronics, IEEE Journal 2014; 20: 2.

King C. Cosmological Foundations of Consciousness. J Cosmo $2011 ; 14$.

Kohn L. The Taoist Handbook. Leiden, Netherlands: Brill, 2000.

Laager F. Sources and functions of ultra-weak photon emission. Master's thesis, The School of Physics, Seoul National University, 2008.

Levin M. Bioelectromagnetics in morphogenesis. Bioelectromagnetics 2003; 24 (5): 295-315.

Lisi A, Foletti A, Ledda M, Rosola E, Giuliani L, D’Emilia E and Grimaldi S. Extremely low frequency $7 \mathrm{~Hz} 100 \mathrm{mt}$ electromagnetic radiation promotes differentiation in the human epithelial cell line HaCaT. Electromag Biol Med 2006; 25 (4): 269-280.

Lisi A, Foletti A, Ledda M, De Carlo F, Giuliani L, D’Emilia E and Grimaldi S. Resonance as a tool to transfer information to living systems: the effect of $7 \mathrm{~Hz}$ calcium ion energy resonance on human epithelial cells (HaCaT) differentiation. In: PIERS 2008 in Cambridge Proceedings. 2008a; pp. 902-906.

Lisi A, Pozzi D, Ledda M, de Carlo F, Gaetani R, D’Emilia E, Giuliani L, Bertani F, Chimenti I, Barile L, Foletti A and Grimaldi S. Resonance as a tool to transfer informations to living systems. In: PIERS 2008 in Hangzhou Proceedings. 2008b: pp. 540-544.

Litovitz T, Krause D, Montrose C and Mullins J. Temporally incoherent magnetic fields mitigate the response of biological systems to temporally coherent magnetic fields. Bioelectromagnetics 1994; 15 (5): 399-410.

Lopez DS. Religions of India in practice. Princeton University Press, New Jersey, 1995.

Lorenz H. Plato on the Soul. In The Oxford Handbook of Plato, G. Fine (ed.), Oxford: Oxford University Press, 2008.

Margulis L and Sagan D. What is Life? New York, NY, USA: Simon \& Schuster, 1995.

Maricela Y and Pierre M. The Light of Life - Biophotonics 2006. biophysics.sbg.ac.at/paper/biosem-yip-2006.pdf

Marino A and Becker R. Biological effects of extremely low frequency electric and magnetic fields: a review. Physiol Chem Phys 1977; 9 (2): 131-147.

Marston RM. Optoelectronics Circuits Manual. Newnes, $1999 ;$ p.192.

Maturana HR. Biology of cognition. In Autopoeisis and Cognition. 1970; pp 1-58. Dordrecht, The Netherlands: Reidel.

Maturana HR and Varela FJ. Autopoieses and Cognition: The Realization of the Living. D. Reidel; Dordrecht, 1980.

McCaig CD, Rajnicek AM, Song B and Zhao M. Controlling cell behaviour electrically: current views and Future potential. Physiol. Rev. 2005; 85 (3): 943-978.

Mead C. Collective Electrodynamics: Quantum Foundations of Electromagnetism, 2000. MIT Press, Cambridge, Mass.

Mehta A. Introduction to the Electromagnetic Spectrum and Spectroscopy. 2011. Pharmaxchange.info. Retrieved 2015-03-01.

Milani M, Ballerini M, Ferraro L, Zabeo M, Barberis M, Cannone $\mathrm{M}$ and Faleri M. Magnetic field effects on human lymphocytes. Electromag Biol Med 2001; 20 (1): 81-106.

eISSN 1303-5150
Miller MB and Bassler BL. Quorum sensing in bacteria. Annu Rev Microbiol 2001; 55 (1): 165-99.

Mitchell ED and Staretz R. The Quantum Hologram and the Nature of Consciousness. J Cosmol 2011; 14.

Musumeci F, Scordino A, Triglia A, Blandino G and Millazo I. Intracellular communication during yeast cell growth. Europhys Lett 1999, 47 (6): 736-742.

Nichols S and Grantham T. "Adaptive Complexity and Phenomenal Consciousness". Phil Sci 2000; 67: 648-670. doi:10.1086/392859.

Niggli HJ. Biophotons: our body produces light, Network 1998; 68: 16-17.

Niggli HJ, Tudisco S, Privitera G, Applegate LA, Scordino A, et al. Laserultraviolet- A-induced ultraweak photon emission in mammalian cells. J Biomed Opt 2005; 10: 024006 .

Niggli HJ. Biophotons: Ultraweak Light Impulses Regulate Life Processes in Aging. J Gerontol Geriat Res, 2014; 3:2.

Nussbaum MC and Rorty AO. Essays on Aristotle's De Anima, 1992. Oxford: Clarendon Press.

Okun LB. Photon: History, mass, charge. Acta Physica Polonica B. 2006;37(3).

Overmann J and Garcia-Pichel F. The Phototrophic Way of Life. The Prokaryotes. 2006; pp 32-85.

Pickthall MM. The Meaning of the Glorious Koran, 1953. New York: Mentor Books, n.d., p. Xxviii.

Popp FA, Chang JJ, Gu Q and Ho MW. Non-sustantial biocommunication in terms of Dicke's theory in: Bioelectrodynamics and biocommunication, 1994. edited by M W Ho, F A Popp \& U Warnke (Worl Scientific Publishing Cp., Singapore-London), 293.

Popp FA. Properties of biophotons and their theoretical implications. Indian J Exp Biol. 2003; 41(5):391-402.

Popp FA and Beloussov LV. Integrative Biophysics: Biophotons. Kluwer Academic Publishers, Boston, 2003.

Popp FA and Klimek W. Photon sucking as an essential principle of biological regulation. Biophotonics and Coherent Systems in Biology. 2007. Chapter 2, XII ISBN: 978-0-387-28378-4.

Pokorný J. Viscous effects on polar vibrations microtubules. 2005. In: URSI GA Delhi Proceedings.

Pokorný J. Herbert Fröhlich FRS: a Physicist Ahead of His Time. University of Liverpool, Ch. The role of Fröhlich's coherent excitations in cancer transformation of cells, 2006. pp. 177-207.

Pokorný J. Biophysical cancer transformation pathway. Electromagn Biol Med 2009; 200828 (2): 105-123.

Portier C and Wolfe M. Assessment of Health Effects from Exposure to Power-line Frequency Electric and Magnetic Fields. 1998. Tech. rep. National Institute of Health.

Preparata G. QED Coherence in Matter. 1995. World Scientific, New Jersey, London, Hong Kong.

Richards A. "Editor's Introduction" Freud, On Metapsychology 1977; pp. 344-345.

Robinson K. The responses of cells to electrical fields: a review. J Cell Biol 1985; 101 (6): 2023-2027.

Rosen R. Life Itself: A Comprehensive Inquiry into the Nature, Origin and Fabrication of Life. Columbia University Press; New York, 1991.

Sahu S, Ghosh S, Ghosh B, Aswani K, Hirata K, Fujita D et al. Atomic water channel controlling remarkable properties of a single brain microtubule: correlating single protein to its supra molecular assembly. Biosens Bioelectron 2013a; 47:141

Sahu S, Ghosh S, Hirata K, Fujita D, Bandyopadhyay A. Multi level memory switching properties of a single brain microtubule. Appl Phys Lett 2013b; 102:123701.

www.neuroquantology.com 
Santini MT, Ferrante A, Rainaldi G, Indovina P, Indovina PL. Extremely low frequency (ELF) magnetic fields and apoptosis: a review. Int J Rad Biol 2005; 81 (1): 1-11.

Scheminzký F. Photographischer Nachweis von Emanationen bei biochemischen Prozessen. Biochemische Zeitschrift 1916; 77: 13-16

Simunovic Z. Lasers in Medicine and Dentistry, 2000. vol. I. Vitgraf, Rijeka (Croatia).

Singh G. Soul of Sikhism. 2013. Diamond Pocket Books (P) Ltd, Kobo Edition.

Sinitsyn N, Petrosyan V, Yolkin V, Devyatkov N, Gulyaev Y, Betskii O. Special function of the millimeter wavelength waves: aqueous medium system in nature. Crit Rev Biomed Eng 2000; 28 (1-2): 269-305.

Slawinski J. Necrotic photon emission in stress and lethal interactions, Curr Topic Biophys 1990; 19: 8-27.

Slawinski J. Biophotons from stressed and dying organisms: toxicological aspects. Ind J Exp Biol 2003; 41: 483-493

Slawinski J. Photon emission from perturbed and dying organisms: biomedical perspectives. Forsch Komplementärmed Klass Naturheilkd 2005; 12 (2): 9095.

Snead C. Cognitive Neuroscience and the Future of Punishment. 2010.

Snowden R. Teach Yourself Freud. McGraw-Hill. 2006; pp. 105-107.

Squire L, Darwin B, Bloom F, du Lac S, Ghosh A, Spitzer NC. "Fundamental Neuroscience, 4th edition". 2012. Chapter 43.

Sun W, Chiang H, Fu Y, Yu Y, Xie H, Lu D. Exposure to $50 \mathrm{~Hz}$ electromagnetic fields induces the phosphorylation and activity of stress-activated protein kinase in cultured cells. Electromag Biol Med 2001; 20 (3): 415-423.

Sun Y, Wang C, Dai J. Biophotons as neural communication signals demonstrated by in situ biophoton autography. Photochem Photobiol Sci 2010; 9: 315-322
Teilhard de Chardin P. The Phenomenon of Man. French: Editions du Seuil, Paris, English: Harper and Row, New York, 1959.

Thackeray St. JJ. The Jewish War Books I-II. Cambridge MA: Harvard University Press, 1997; pp. 384-387.

Tuchin VV. Light scattering study of tissues. Physics-Uspekhi 1997; 40 (5): 495-515.

Tuner J and Hode L. Low Level Laser Therapy. Clinical Practice and Scientific Background. 1999. Prima Books, Grangesberg (Sweden).

Van Wijk R. Bio-photons and Bio-communication. J Sci Explor 2001; 15 (2): 183-197.

Van Wijk E, Kobayashi M, van Wijk R and van der Greef J. Imaging of ultraweak photon emission in a rheumatoid arthritis mouse model. PLoS One 2013; 8: 84579.

Ventura C, Maioli M, Asara Y, Santoni D, Mesirca P, Remondini D and Bersani F. Turning on stem cell cardiogenesis with extremely low frequency magnetic fields. The FASEB Journal 2005; 19: 155-157.

Vogel R and Sübmuth R. A model for the generation of low level chemiluminescence from microbiological growth medium an its depletion by bacterial cells, Biochem. Bioenerge 1998; 45: 93.

Woods M. Plato's Division of the Soul. Proceedings of the British Academy 1987; 73: 23-47.

Wright NT. Surprised by Hope: Rethinking Heaven, the Resurrection, and the Mission of the Church. New York, NY: HarperCollins, 2008.

Young DJ. Does Aristotle Refute the Harmonia Theory of the Soul? Open J Phil, 2013; 3 (1): 47-54.

Zhadin $M$ and Giuliani L. Some problems in modern bioelectromagnetics. Electromag Biol Med 2006; 25 (4): 227-243.

Zrimec A, Jerman I and Lahajnar G. Alternating electric fields stimulate ATP synthesis in Escherichia coli. Cell Mol Biol Lett 2002; 7 (1): 172-175. 